\title{
I, Thou, and the Sphere Between: Reflections on Dancing Difference in One Direction
}

\section{Cover Page Footnote}

In acknowledgement of the significant collaborative effort behind this creative project, I owe special thanks to Ghulamsakhi Alizada, Barat Mohammadi, Arsalan Soltani, Alireza Ghorbany, Mahdi Nagisade, and Malia Bruker, as well as Susan Ossman of the Moving Matters Traveling Workshop, and David Bernard at Gängeviertel/Fabrique for their generous hospitality and inspiration at various stages of this work. 
Facing each other, we stay only inches apart. A tiny camera strapped to my chest and another around his forehead, we move; mirror images at first and then always in relation. You extend an arm to let me scan it with my lens. That moves me sideways, twists me; I tilt. A leg lifts and you dive underneath, into the areas where I am not. Turning away means losing you completely, so I stay right over you, then under you, tracking you as you track me back. It is June 2017 at the Berlin Wall Memorial's Church of Reconciliation, and Sakhi and I are invited guests of an installation and performance hosted by the Moving Matters Traveling Workshop, where artists and anthropologists are sharing visual art, poetry, and short stories on the subjects of walls and migration.

In the middle of the standing crowd, we record our small sphere of relation. The rounded, bulbous frame of our fisheye lenses attend to our task: seeing each other seeing each other. ${ }^{1}$ What we danced meant to deal with who we were, close but still new friends, for whom the added digital devices worked like strange mirrors of intimacy and distance, reflexive walls delineating ourselves in view of the other. Our duet lived in this spatial and temporal sphere of between-ness, as did our relationship with one another over the past year; me, a Jewish American granddaughter of the Holocaust having returned to Germany with a family story to tell, and Sakhi-a recent political émigré from Afghanistan. Together, we danced, two exiles across difference; as Sakhi once described it, "in one direction."

This duet extends a larger performance project, which for the sake of this essay and its reference throughout, I will call Dancing Exile. What has otherwise developed without a title, or with shifting titles depending on who is in the room and what we are doing (most often referred to as "Tanzkurs" or "Dance Course" by participants) has aimed to underscore the work of political and artistic representation in Hamburg, Germany. My engagement in the project stemmed from an interest in the connections between past and present exiles, and their relation to the cityscape, the site of my Jewish family's Holocaust history. Collaboration with performers from Afghanistan, the United States, and Germany has provided multiple opportunities to reflect on the contemporary experiences of new immigrants, for whom the city offers the hope of political and economic refuge. In what follows, I discuss the aesthetic and social dynamics of these themes in relation to questions of migration, mobility, and relationship. 
The essay is organized around multiple ways of situating the project and its stakes. First, I outline the project as it has developed since May 2016 across three movement workshops, two live performances, an academic conference presentation, and a dance film production shoot. Moving chronologically through these phases to reveal the work of co-creation, I frame the Dancing Exile project in terms of relational dynamics by drawing on the choreographic potential of Martin Buber's seminal philosophical text, $I$ and Thou (1923). Then, I consider the project in the context of a larger post-migrant theatre movement, theorizing what dance improvisation adds to a growing politics around intercultural performance practices in Germany. Finally, I suggest the project's reparative value, emphasizing not how it aims to fix the problems of immigration, but how it may help to structure some degree of change for participants and audiences through humor, connection, and a shared but diversified sense of direction.

The Dancing Exile project began in May of 2016 when I joined a governmentsponsored German language class for refugees that took place at the Israelitische Töchterschule, the former Jewish school for girls, where my grandmother attended during the years leading up to World War II. I was there to screen a site-specific dance film I had choreographed in the same building the year prior, with director Malia Bruker and a cast of German middle school students. ${ }^{3}$ A growing number of government-sponsored language classes had been taking place there in the year since we had shot the film. ${ }^{4}$ I was struck by the building's dual purpose: to memorialize past experiences of exile while facilitating new ones; and after a week of joining one such language class, German teacher Julia Freienberg allowed me to propose an idea for a Saturday movement workshop in the bits of German I had learned: Möchten Sie am Samstag einen Tanzworkshop über die Geschichte der Flüchtlinge hier in Hamburg besuchen? "Would anyone wish to join me for a movement workshop on Saturday on the subject of refugee life in Hamburg today?" Nearly all classmates raised their hands, and the group of ten 1845 year old men from Afghanistan joined me, Malia, and three additional friends from Hamburg who were interested in the project and offered to help with Pashto, Dari, German, and English translation. The aim was to see how dance could build alliance and support through a collaborative exchange tied to place, but outside of its sanctioned parameters around who should move and how. 
As a group, we were mostly outsiders coming to Hamburg with different resources and in search of entirely different meanings. For me, it was a movement into my past, and for the group from Afghanistan, an urgent process of acclimating to new circumstances. The German I was taught never to learn now became a way to relate, not to Germans, strikingly, but to Germany's newcomers, where the few words we would exchange carried meaning beyond what they could with native speakers. In this context, simple cues in limited German acted like small movement partnering prompts with big implications: Pull/Resist, Towards/Away, Help/Don't Help, and a partnering exercise I call Lingering, but which we called in Kontact Bleiben, or Staying in Touch, which came to assume many additional meanings. We used words we had learned in class, relying on their physical demonstration to make sense of the concepts as dance ideas as well as their translation across the many languages in the room. Then, at a certain point, and unprompted by me, participants began to embody, without words, the events of their past. Arsalan rescued a body from the ocean, washed up on the shoreline. Barat became the Polizei. Wali locked his wrists as if handcuffed, and Beatrice became a limp thing the others carried across the room to resuscitate. The group of us said nothing for several minutes of action against the sound of heavy breathing and whispers. After that, Abdul began to narrate what was happening. Many, as Abdul said on camera that day, "were on the way for three months or more," adding, "it is impossible to tell all." workshop, Sakhi translated for Barat. "Sometimes we can say by our speech that we have this problem, or we can show something by speaking. But in here ... I can show something, what is happening in my heart. Without speaking, it is the first step that I can easily do for other person with my gesture."6

In December of 2016, I returned to the space where we had met in order to continue with Sakhi, Arsalan, Alireza, Barat, Abdul, Firouz, Wali, and local contacts Mahdi and Beatrice. Malia was on camera, and there were a small handful of Hamburg artists and activists associated with Gängeviertel who were also present. The upstairs seminar room offered an ideal setting for the project, whose central aims fit well within the mission of this volunteer-run hub for creative experimentation and political organizing in the downtown district. ${ }^{7}$ Outside the workshop it was Christmas-time, and the city was filled with street markets, mulled wine and German fare. Elaborate 
installations of gingerbread men and quaint "country style" ornaments celebrated a striking nostalgia for a time long past — since 2015, this city had experienced a significant demographic shift with the influx of political and labor immigrants. I noted the growing number of young brown and black men walking alone or in groups, and the less visible presence of migrant women, both on the street and in the language classes I went back to visit. $^{8}$

The gender gap was also reflected in our group, where the core collaborators were Afghan men and women from the US and Germany. Cultural traditions and different dance backgrounds dictated how we would or could relate to each other; whether because of cultural prohibitions regarding dancing between men and women, or any number of other factors influencing comfort levels among new friends. When it came to how gender dynamics played out in dancing, many in the group were single and said that dancing between genders started to feel romantic. Others preferred to dance closely only with their own gender, as is allowed by cultural norms. Three men said they imagined a malefemale duet while dancing with another man. A woman living in Germany, but with roots elsewhere, preferred to dance alone for reasons she didn't wish to explain.

A week together made time for these variously gendered groupings to take shape and change, as movement exercises built more familiarity among the group, and in turn, generated material dealing with difference itself for a culminating performance. We called the evening of improvisation "The Art of Confusion" after the same expression a friend used to describe the legal situation for new immigrants. It was a fitting name for our range of talking and dancing scores on the topics of translation and mistranslation, connection and rupture. The atmosphere was warm, with an open-ended feel, as friends and colleagues came to our workspace for the loose start time. Some cast members escorted guests to the communal kitchen on the first floor, where they could help themselves to Mahdi's sabzi (spinach and red beans) to eat during the show. ${ }^{9}$

This kind of welcome aimed to invite audiences into our project through a gesture of generosity and togetherness. While not unfamiliar with performance events oriented around relationship building, the place-specific aspects of this hospitality offered a critical refiguring of host and guest roles. In the context of Germany's "outsiders," as new immigrants are often called, and as I also feel as a Jewish American returning to find 
roots there, this opportunity to play host for the mostly German guests offered an important inversion. In a political moment when emphasis is placed on the assimilation of refugees under the banner of national hospitality, the potential of coming together for the sake of creating alternative spaces to share is both generous and complex. Feeding local audiences in this layered sense raises questions about what it is to offer up outsider insights through performance, even as it answers with perhaps the most hospitable resolve: to come together with positive energy and delicious food.

Somewhere amidst this "living room" feeling, Barat and I started our duet on the couch, drawing on the kinds of physical play he and I had established, despite not sharing a spoken language. ${ }^{10}$ We made our way to a chair, and he hoisted me up to stand on its seat. He offered his back as another support, and I climbed even further on top, perching on the makeshift risers to address the small crowd of friends and colleagues. Hello and Willkommen, I say. Thank you for coming. I thought we'd begun, but I looked to Sakhi who was delayed with the sound cue. I played it cool and walked over to him for a private conversation as the audience watched. Now is good, I told him. OK, he answered, scrolling through YouTube songs on his iPhone. Wir Beginnen, I announced too quickly, and he didn't answer. Then, after a moment of anticipation, his pick-Shakira - saved the awkward seconds of silent waiting. Leonie, Arsalan, Sakhi, Barat, Alireza, Mahdi, Malia, and I rushed the makeshift stage, and with a gestural wave, so did two small groups of our guests.

Arsalan and I made eye contact to begin our section, a copy-exactly game where we do the same thing at the exact same time; something we manage impressively well so long as he leads and I follow. He seemed shy in front of the crowd, restricting his movement choices as the others found their seats, so I didn't let it go on too long. Continuing to direct the flow from the inside, I broke duet focus and moved towards a table, glancing over to Sakhi and Leonie who joined me there for "Übersetzen" (Translation), a trio designed to comment on itself. The rule was to move between languages the others know and do not know and to decide when and if to agree or disagree. An especially poignant moment of the score was when Leonie, a soft-spoken Hamburg native, played the Übersetzer (translator) as Sakhi and I sat on opposite sides of the table. Taking advantage of her physical relationship to him as she climbed up and 
over his chair to perch on its ledge behind him, I said to her in English, "Tell me what you think he's thinking," stretching the terms of what translation means. "He thinks you should be more careful," she replied, also in English, to which he raised his eyebrows as I slid slowly off my chair. Draping my weight as precariously as possible, I replied, "is this careful enough?" wondering in real time how to account for the violence of representational performance on refugee experience that may seem so lopsided if I am coming and going so sporadically and at will. "No, I don't think so," Leonie said. Neither she nor I included Sakhi in the conversation, talking to each other rather than "translating" the exchange as was indicated by the rules of the game. While Sakhi needed no translation, as he could easily understand our English, the exchange deliberately revealed the kinds of power dynamics and discussions of power dynamics taking place between privileged people-well-meaning white women especially-on the fate and feelings of new immigrants while being right in their midst.

The score was inspired in part by a duet improvisation that Sakhi and I performed next: a piece called "Light Contradictions" choreographed by my mentor, Los Angelesbased choreographer, Susan Rose. Playing up the interchanges of power dynamics, "Light Contradictions" is a game of wits where dancers hurl commands at each other while attempting to accomplish what the other has just instructed them to do. ${ }^{11}$ When sharing the score with Sakhi earlier that week, two things had become immediately clear: 1) Such confrontational communication, and with a woman no less, was entirely outside Sakhi's comfort zone, and 2) The focus on contradictions allowed for any number of political and personal dynamics to come to the surface. My readiness to parody power needed explanation and negotiation, as the duet's mode of quick, abrupt verbal and physical commands jumped so completely outside of our usual mode of polite communication. As I had framed it, we could use the exchange to exaggerate the absurdity of a world bent on ordering other people into action or non-action by way of bossing each other around. Sakhi laughed at the premise, asking why he should be like these people. "Maybe you are the only person I have ever met who is not that way," I said. "Thank you," he said. "Let us try." Altering Rose's original score to allow for more respectful delivery of verbal instructions was a partial answer. We added "please" and "thank you" to every movement directive; Sakhi liked it better that way, even though we 
were making each other do ridiculous things. We asked nicely to "please stand over there," and once either of us moved, added a quick "but no, not there, over there, please," and this mode of address mocked a world governed by endless commands and corrections. In the German context, this resonated with the rules Sakhi explained that had characterized his experience moving to this country, while also recalling the seemingly endless instructions that regulate the refugee experience. The duet gave way to a number of improvisations among the larger cast that ranged from helpful to interruptive, deliberately careful or the opposite.

Many in the audience at that performance remarked on how synchronized we seemed to be, and how difficult it was to believe that the piece was all improvisation. Others were not so positive, put off by aspects core to our collaboration. One white, middle-aged German woman noted her frustration at several moments when she could not understand the multiple languages spoken throughout. It was upsetting for her not to have translations for the Dari, Pashto, English, French, and Spanish text; let alone the lack of program notes for the improvisation structures we were performing that might have explained what they meant. While it was not the intention of the work to alienate her, members of the audience replied that this was an ironic response in light of the topic. That she assumed she would or should understand everything that was said in performance, or at the least that we would ensure that she could, revealed an important aspect of our project's inherent power play. When working to make performance about estrangement and belonging, the question of translation is paramount. Whether and how to render legible one's experiences for those who may demand to know is always charged. In the context of forced migrations to and from Germany, as well as a performance event geared toward the embrace of difference, this need for transparency seemed especially poignant. ${ }^{12}$

Another member of the audience, a friend who had fled his home country twenty years before, waited until after the event to express his feelings. These men, he told me, do not need this. They need bread, medicine, and the ability to work. ${ }^{13}$ At the time, I didn't repeat his feedback, not wanting to complicate the good feeling shared by performers about what we had done. I shared this comment with Sakhi months later when we began to collaborate on the next stages of our project. "It is important for cultures to 
come together," he responded after a pause. "It is so difficult, but also, so nice." And what is so difficult and so nice, I asked. "Other countries, separate cultures, separate places, separate issues, separate positions, but in one direction of idea ... to go with theatre and gather the people in heart and peace." 14

It is clear that performance cannot compete with the urgency of basic needs. And yet, it is also clear that performing together has offered a way to move among restrictions inside and outside of spoken language. Shared experiences of place have provided mechanisms of support for new migrants, despite increasing political uncertainty, and in the case of this group, the real threat of deportation back to Afghanistan. ${ }^{15}$ It is important to note that since meeting the group last summer, Sakhi is the only one to have received asylum, due to both his language proficiency and his ability to make a strong case for his need to stay in the country. After two years in Hamburg, Sakhi's German is very good, and he can prove that he has no choice but to stay in Germany. Others in the original group still wait for news, caught in the tangle of asylum interviews and less than clear results.

It is because of Sakhi's more stable status that the project has continued, largely as a duet. It has meant we could move forward with our plans to co-present at the Performance Studies International conference taking place in Hamburg in June of 2017, shoot a dance film there, and continue to develop duet material for an invited performance at the Berlin Wall Memorial. For these engagements, we sought a mode of working that could reflect upon our ways of working together, while continuing to explore what that actually entailed. I shared Martin Buber's seminal philosophical essay, I and Thou, written in German in $1923 .{ }^{16}$ The text, core to progressive Jewish theology but widely accepted beyond those bounds, describes the godliness that exists in the "sphere of betweenness" which takes shape in the ways people treat each other. And while Buber does not discuss performance or dance directly in the text, there exists rich choreographic potential in his description of an I-Thou world of relation that requires what he simply calls "body" to bring to life. ${ }^{17}$

This "bodied" sphere of betweenness that Buber invokes brings attention not only to the potential of embodiment as a physical realm of mutual relationality, but also to the possible outcome of moving together, and of improvising, as a practice of "godly" 
meeting. ${ }^{18}$ Abstract as such a premise may be for many, the question of godliness underlined all interactions between Sakhi and me, as well with several other members of the group. My Jewishness, the degree to which I observe Biblical law or not, my orientation to prayer, when and how I do it, to what extent it informs my life choices had shaped our conversations about dating, marriage, family, children, and a spiritually rooted sense of justice. For Sakhi, a practicing Muslim, these questions were pertinent not only to us getting to know each other personally but as entrance points to a new life in Germany that hinge on exactly this kind of intercultural exchange. As a Jewish American with German roots in Holocaust history, this last point is profound in its reparative potential, which connects to place and across time. It is clear enough that the effects of war cannot be mended, "then" or "now"- through dance or any other means. And yet, the Hamburg-specific "post-migrant" frame supports a creative realm that "bodies" forth a sphere of betweenness experienced differently for each partner.

This emphasis on different entrance points and embodied reflections on that difference grounds how our project adds to and expands a discourse on post-migrant theatre in Germany, and its implications for dance improvisation. As a growing framework for political performance, post-migrant theatre responds to the homogeneity of voices in German theatre at large by posing a kind of "Kampfbegriff," or what its leading proponent, Berlin director Shermin Langhoff has referred to as a linguistic tool with which to fight or make a point, rather than define the work of particular artists. ${ }^{19}$ In Azadeh Sharifi's keynote address on the subject to the 2013 Europe Now Festival, she described a movement working to refer "to the social, political and cultural phenomenon which affects the whole society." 20 Adding that this demands attention to racism, Sharifi argued that post-migrant theatre can invite important reflections on the social and structural conditions of violence that have continued to keep voices of color outside its stages and audiences. This is necessarily political, in the sense that it broadens the scope of theatrical representation. ${ }^{21}$

Dancing Exile fits well within this political theatre frame and stretches its dancerly potential. Our project's emphasis on relationality locates itself in place and time, whilst also physicalizing a discourse on difference and discrimination, wherein improvisation crafts a practice of structuring change on personal and political scales. ${ }^{22}$ 
The intimacy of dance partnering and its sustained focus on the "I and Thou" of relation provides ideal terms for doing work on multiple scales at once. This scaling and rescaling of micro and macro elements is yet another implication of dancing difference in one direction. How we make decisions in the real time of performance, from the ways we share the simultaneity of lead and follow in tightly rule-based exercises, to the wide openness of the words we exchange in unstructured talking scores, reflects on the working dynamics of our collaboration. These dynamics not only reveal significant possibilities and challenges of intercultural work but recognize the power such dynamics can yield. This was especially evident when Sakhi and I pieced together fragments of conversations from our Facebook messages, phone calls and emails to read out loud for an academic presentation on the "choreographies of migration and flow" as they related to our project.

In the script we compiled, Sakhi opened one section of text with: "Sometimes in my room, when I close my eyes, I feel that I am right now in the place that I should think about dreams. I faced many problems ... I think, if you move yourself here, you should make it your future here." I asked in response, "and what do you wish for your future? Or what would you like to share of your past?" There was then space in the script for Sakhi to choose whether to talk or remain silent, move or be still. While not the only openended section of our presentation, Sakhi's choice as to what to share about his past was the most deliberately crafted element. We agreed on five sections that could either happen in order or not, as either of us saw fit. Reading what we wrote and adding anything else that emerged, copy exactly until we wanted to do something else, Mis/Translation, and Staying in Contact, and finally, "Unsere Geschichte"-which means "Our Story" and also "Our History"- had no set parameters. To mark duration, we set a kitchen timer, a grey plastic mouse we wound to twenty minutes. The presentation sought out a mode of sharing what we do while we do it, and rough as it was from a performance point of view, our co-panelist spoke about an intense degree of care shared between us which she found most significant.

As relative as a concept of care can be culturally or personally, we have since named it as the core aspect of our project agenda and intention, aiming for it at every turn. Anthropologist Jonas Tinius adds political dimension to the issue of care when he 
underlines the significance of how post-migrant theatre projects come together. His research on refugee performance emphasizes the issue of who and what initiates this kind of collaborative environment, when questions around vulnerable populations with uncertain legal status are at stake. ${ }^{23}$ My reasons for initiating this project established the starting point for me, although not for the others. While Sakhi and I speak intimately about our families, my interest in Jewish history as it relates to contemporary refugeeism has not been the most pressing issue for others who form relationships with me and to each other on any number of alternative terms. Still, with each new member of the group, I was asked why I care about the refugee experience, and what I wanted to do with this project. Each time I explained that my family story brought me here in the first place, and now it is because of these relationships that I want to continue. Many questions continued throughout the workshop days, addressed both to me and by me about the goals of the project, the idea of art on political themes, the difference between literalism and abstraction, of dancing versus acting, and narrative versus non-narrative storytelling.

Inspired by the content and pitch of the conversations, and the range and depth of topics raised for discussion, we have also tried talking and dancing scores inspired by the questions themselves. One such score, borrowed from familiar theatre games, instructs two people to carry on a conversation, but only through questions. Resisting the urge to answer each other outright, the nature of what happens explores an infinite range of ideas, addressed only through asking for more about what they bring up. The exchange throws everything up into question, making space to ask anything one might think to ask while living with not knowing the answer. Why are you here, what do you want me to tell you, what do you want me to know, where did you come from, where did you get that scarf, who wants to know, when do you need me to tell you, can you say that again, what language are you speaking, what language do you want me to speak, do you want me to understand you better, do you understand me better in the morning or afternoon, what time are we meeting later, and so forth. Allowing space to question each other in these ways has created modes of negotiating a vast number of differences that take shape and fall apart between communication partners, whether in words or dance.

This kind of questioning, and questioning of the questioning, brings humor to Buber's betweenness through its resistance to scripted exchange. It opens a space to seek 
out new dynamics, mocking that which we may think we want or need to know about the other. The premise disinvests in everyday objectification through its open-endedness, its spontaneity, and its basic turn-taking, and in doing so, extends into territory beyond the questions themselves. This "method" aims to approach what Buber defines as betweenness (Zwischen) or "the immediate presence of unreserved, spontaneous mutuality common to each person, yet beyond the sphere of either." ${ }^{24}$ Impossible to objectify, "the between" in Buber's estimation is the most authentic reality of human existence, of being wholly and uniquely "human" with humans. ${ }^{25}$ Where Buber's model is built on unreserved, spontaneous mutuality, such improvisatory structures as outlined above invite a parallel openness to the theatricality of what happens between people as they enact scenarios reflecting on social or political life. And yet, if within the Dancing Exile project, our uncoordinated, open and rotating direction is to be Sakhi's idea of the "one direction," this poses an important challenge for a project oriented around multiple voices, endless techniques, and infinite possibilities. This, for me, is a question not only of philosophy but of craft; not only of what and why but of how.

As the Dancing Exile project continues to develop strategies for performance, it has been helpful to engage with other projects that are part of a post-migrant theatre frame. For artistic director Adem Kösterel of Ruhrorter Theater in Mulheim, Germany, for instance, it is necessary to actively resist the mediatized image of the refugee by refusing to perform authenticating tragic stories of national wars, which in turn serve an agenda of national cultural integration. ${ }^{26}$ As Jonas Tinius writes in his ethnography of Ruhrorter Theater, Kösterel's strategy of fictionalization trains participants to cultivate a distance from their own histories as part of a critical subject formation that is at once detached from one's lived experiences and self-reflexive. ${ }^{27}$ The danger Kösterel cautions against is the internalization of one's story as one's self, which may risk rendering individual plights as only personal, rather than deeply affected by structural concernssomething he finds disempowering for performers and audiences alike. Why fiction helps in this view is because it opens up an imaginative realm wherein actors have limitless capacity to enact new scripts. From this view, participants need not detach themselves from the realities of migration as they may play out in performance, but instead, a range of distinct experiences can be shared among performers and audiences without rendering 
anyone as a person to either pity or possess.

In Dancing Exile workshops, identification has not been explicitly off-limits, and our methods for making performance have been far less definitive. As we have moved readily through both structured and unstructured improvisations, the content of what has emerged has ranged widely. In several cases "identification" has seemed the most pressing concept at play, posing the most urgent stories to enact. As mentioned above, some participants used the workshop environment to replay events that happened to them. In other cases, the abstraction of dance partnering on themes like spatial relationship or helping/not helping has moved between more and less narrative encounters. When one person has an idea, we try it. We are not engaging in a monthslong rehearsal process. We are also not committing to a training model with one artistic director. While participants often refer to me as their dance teacher, it is often said with a smile and a laugh, as if we are now gathering as a group of friends with less clear delineations of who is in charge of the time together, and what we will make. Spending intensive but short stretches of time together, we have discovered what we want to share with each other, what boundaries we are willing to cross or compromise in order to collaborate, and what commitments are taking shape that will either support the work or complicate it. We, a group of Is and Thous, aim to share the lead in one direction, but in multiple ways.

In this sense, the "post" of post-migrant theatre opens important areas for continued consideration as it conjoins both temporal and ideological aims to artistic ones-purposefully, under ongoing review, and where everything matters. And yet, in its most rigid application, the "post" frame suggests an after-effect of migration, a concept reaffirmed by usages of the post-migrant term for German children and grandchildren of migrants wishing to be seen as Germans. ${ }^{28}$ This is an odd fit for myself, for whom my father has tried and failed to receive "restored citizenship" in the country, ${ }^{29}$ and my collaborators, stateless refugees for whom the event of migration is far from over. Still, even as I partner these two migrations under the banner of the German "post-migrant," I knowingly risk conflating distinct contexts that cannot claim a shared "post" concept. To be sure, the "post" in each case carries with it a unique practical and temporal proximity to change, whether to the trauma of displacement or other, more positive changes. 
As post-migrant theatre includes an ever-broader population and scope, it opens up boundaries around who can make performance, with whom, and regarding what migration histories, time frames, and conditions. ${ }^{30}$ Such practice also raises important challenges to performance that deals with migration processes as continuance rather than finality, events that take shape as they move forward, rather than ending with the movement from place to place. These reflections move beyond a strict compartmentalization of history, and one whose categories for people deconstruct and reconstruct subjectivity. Rather than Its to be integrated, accepted or rejected, the choreographic potential of I-Thou, through the Dancing Exile frame, invites a transformation of self in relation to others.

There is no doubt that when dealing with topics like migration, outsider-ness, and converging histories tied to place, we must continue to address the question of representation itself, and in doing so, its limits. For this closeness and distance, and the uncertainty of what comes next, we need humor (and more Shakira) to "body" it forth. Such a premise structures change on interpersonal and intercultural scales by way of scoring real possibilities of dancing difference, in order to gather people together in heart and peace.

Through our workshop and performance perspectives, we understand that the kinetic, theatrical expression of difficult experiences can help render these experiences more legible for audiences and participants. At the crux of this is a practice of attending to change that can enact significant shifts of power on multiple scales. As we mobilize ideas through talking and dancing scores, improvisation has the potential to open up space for negotiation; the opportunity exists, especially through dance partnering, for interpersonal and political alliance. Choices are not necessarily understood as the same by all, but an underlying acceptance of what the other offers gives participants a premise for moving forward.

Finally, as Sakhi wrote to me in advance of our most recent performance, "If somebody has a heart, you should tell your story. If somebody has pain, you can tell your story. But if somebody does not feel you, and you tell everything for her or him, it would be like it is nothing ... It is because of this we need more time together." Feeling this too, I arranged the next trip. "You know," Sakhi added, “... I feel more things, but I cannot 
say. Instead, I pray and say for God.”

I wrote back, "and if God lives between two people?"

"Then the dance is good."

${ }^{1}$ It was the intensity of our shared gaze that we both agreed had stood out in past improvisations, and which we meant to foreground with our wearable cameras. What is it to be seen, or invited to see? asked our Go Pro cameras. We set our slowed tangle just beside two panels of painted eyes (Eyes by Beatriz Mejia-Krumbein), globs of visibility textured in layered peaks of gold flake, adding so many more "looks" on our dance about looking.

${ }^{2}$ Facebook messenger exchange with Sakhi, May 27, 2017.

${ }^{3}$ Our dance film Klasse was shot on location in the historical classroom upstairs, a Holocaust memorial site where letters written between my grandmother and young friends are on permanent display. Performers: Samuel Aldenhoff, Lenny Bucher, Athena Fahimim Vahid, Helena Fahimi Vahid, Luka Kiwus, Susanne Nazarigovar, Yannick Walter-Krieger, Selin Yasar, Cydney Watson, Crystal Sepúlveda, Amanda Waal.

${ }^{4}$ As of November 2015, one million migrants arrived in Europe via illegal routes. Germany now houses the highest number of refugees of all the European countries, establishing policies of political asylum that, while generous, remain impossible to grant for the huge numbers in need. Afghan refugees are especially present in Hamburg, where the city is now home to the largest population in Germany. Between January and October of 2015, 124,000 Afghans requested asylum in Europe, according to the UN refugee agency. This is more than twice as many as in the previous year. Afghans are the second-largest group of asylum-seekers in Germany after Syrians, and the fastest growing. Justin Huggler, "Germany to Start Sending Back Migrants from Afghanistan, According to Reports" The Telegraph. 26 October2016. http://www.telegraph.co.uk/news/worldnews/europe/germany/119560 07/Germany-to-start-sending-back-migrants-from-Afghanistan-according-toreports.html. Most Afghans are traveling alongside Syrians via the Western Balkan and Eastern Mediterranean routes. Phoebe Weston, "Mapped: How the Way Migrants Come to Europe has Changed in 10 years" The Telegraph. 30 September 2015. http://www.telegraph.co.uk/news/worldnews/europe/11890892/Mapped-Howthe-way-migrants-come-to-Europe-has-changed-in-the-10-years.html.

${ }^{5}$ See footage of the workshop online in Hannah Schwadron, "Lessons Learned from the Past: Movement, Memory and the Stateless: Part II" Dancer-Citizen, Issue 4, Spring 2017. http://dancercitizen.org/issue-4/following-up/hannah-schwadron-and-maliabruker/

${ }^{6}$ Ibid.

${ }^{7}$ Sakhi, Arsalan, Alireza, Barat, Abdul, Firouz, and Wali were members of the original group from the German language class, all from Afghanistan and seeking political asylum in Germany. Mahdi is a human rights activist from Iran, a resident in Hamburg for 12 years, a bee-keeper, and a housemaster at the Israelitische Töchterschule. Beatrice is a local artist, dancer, and activist associated with Gängeviertel. Malia is the filmmaker who worked on dance film Klasse with me, and 
who returned to Hamburg in December 2016 to continue project development and spend time with the group.

${ }^{8}$ My efforts to invite the few women that I meet are fleeting moments of polite exchanges about the project that end there. In one instance when I visited new language classrooms to introduce the project, I reiterated privately to two young women after class they I would love to include them, and that we could meet without men if that were best. We smiled a lot and they said they would try to make it. They asked me to write down the address but they did not come.

${ }^{9}$ Mahdi, a regular volunteer and well-regarded chef at Gängeviertel's “people's kitchen,” arranged our use of the top-floor seminar room that week, and prepared the meal as a core contribution to the project. A human rights activist from Iran and also a political refugee, he also acted as translator and dramaturg in the sense of sharing critical perspectives on the need for artistic expression and connection for this group.

${ }^{10}$ When we first met in May, our German language teacher took the class on a field trip to the farmer's market. While walking from the metro station, Barat pulled a weed and stuck it in my nose. In an instant, my face flared up in an allergic reaction that made me cry from both fright and, strangely, delight, causing fifteen men to come to my rescue. Since then, the instance has become a repeating inside joke between Barat and me, which we make with the slightest gesture toward a plant, a nose, or the action of giving each other a pantomime gift. To this day, our only untranslated spoken exchange has been to call each other Bruder or Schwester, respectively (Brother and Sister).

${ }^{11}$ Susan Rose choreographed "Light Contradictions" in 1978 and the duet has been part of her company's repertoire ever since. I performed the piece with the company from 2007-2013, during which the company traveled to Shanghai, China to perform the work with local dancers as a practical and theoretical comment on intercultural performance. Rose allowed me to include the score as part of the December workshop "Art of Confusion" performance, which can be seen here: https://vimeo.com/198747715.

${ }^{12}$ In a rehearsal with the Moving Matters Traveling Workshop in Berlin months later, in which Sakhi and I took part, I impersonated this same German woman from our previous audience, interrupting a free verse poem he was reciting in Dari to demand in German that he explain what he was saying. When he started to translate it into English, I interjected further, "No, not translate. Explain it. How do you expect me to understand you if not?!" The other artists - a mix of cultural anthropologists and visual artists from many western countries-did not know about the woman's reaction months earlier, but reacted with a range of intrigue and dismay. Interrupting his poem and his native tongue was a violent act I performed as if it was my entitled right to demand his transparency. While we didn't keep the exchange in the performance due to the discomfort of the others in our group, it was an instructive disruption of the rehearsal process that aimed to provoke rather than resolve the issue of transparency versus a "right to opacity" akin to what Édouard Glissant articulates in "The Thinking of the Opacity of the World" Frieze d/e, Winter 2012, Issue 7, p 77-77, 1 pg. 
13 While directly informed by the difficulty of his experiences coming from war, the comments also repeat an age-old criticism of community-based work. See Jan Cohen Cruz, Engaging Performance: Theater as Call and Response (New York: Routledge, 2010). She debunks the idea that there need to be mutually exclusive measures for artistically excellent or socially efficacious art production, and advocates on behalf of a critical "call and response" between performers and audiences that engages the political work of performance as real work.

${ }^{14}$ Gulamsakhi Alizada and Hannah Schwadron, performance-presentation text for "Choreo-Histories of Migration and Flow" Performance Studies International conference, June 12, 2017, Hamburg, GE.

${ }^{15}$ As of summer 2017, more than 50 percent of asylum claims from Afghans were rejected in Germany. Those turned down are not deported because of the uncertain security situation but are allowed to remain in Germany, in legal limbo. The German government is asking the EU to negotiate a repatriation agreement with Afghanistan so they can be safely returned, and yet, there is no consensus on whether or not the country can be considered safe, even in relatively stable cities like the capital, Kabul. For more on this, see Thomas Ruttig, "Afghan Exodus: Afghan Asylum Seekers in Europe (3) - Case Study" Afghan Analysts Network. 7 February 2017. https://www.afghanistan-analysts.org/afghan-exodus-afghan-asylum-seekers-ineurope-3-case-study-germany/. As of January 2018, appeals of rejected asylum applications are increasingly successful, however. See http://www.dw.com/en/almost-half-of-rejected-asylum-seekers-in-germany-winningon-appeal/a-42155593

${ }^{16}$ Martin Buber, I and Thou, (New York: Touchstone, 1970), trans. Walter Kaufmann. There are several translations of this seminal text from 1923, which for those who study it regularly remind presents an important interpretive challenge and opportunity. See, for instance, Kenneth Paul Kramer, Martin Buber's I and Thou: Practicing Living Dialogue (New Jersey: Paulist Press, 2003). The poetic opacity of the original text and the grappling with it for translations into English resonates with the multiplicity of understandings core to the Dancing Exile project, where a certain untranslatability offers a chance not only to think about the world, but humanize it.

${ }^{17}$ I encountered the text at a Jewish arts conference in Spring 2016 where the quintessential piece of Jewish philosophy came up several times in discussion of a Jewish aesthetic. Intrigued by the premise of a Jewish aesthetic informed by what several cited as Buber's "sphere of betweenness," I began my study of the text through an embodied approach, leading the conference's Jewish Dance Lab through a series of duet exercises designed to physicalize the concept. I had come to the conference with an aim to workshop a movement approach to Jewish intimacy with the all-women group of scholar-artists. What emerged from the dancing and discussion informed what I then brought to Germany in June 2017 toward the continued collaboration with Sakhi and the production of a dance film with members of the group called quite citationally, Between I and Thou (Dir. Hannah Schwadron and Benjamin Mandos. 2017, 14 min).

${ }^{18}$ In Buber's frame, the cherished thing of the duet relationship is its sacred, contemplative realm, wherein the "I" is transformed because of the way it perceives 
the other as a "Thou" rather than an "It". It becomes a thing to possess, rather than a partner. The land of Its is one Buber says we cannot avoid. And yet, the treatment of others as Thous and not as things brings into stark focus the central terms of collaborative representation, and how dance improvisation offers a distinct mode of dancing difference, as Sakhi says, "in one direction."

${ }^{19}$ Neco Celik, "postmigrant Theater," The University of Edinburgh, http://www.blogs.hss.ed.ac.uk/neco-celik/postmigrant-theatre/

Cory Tamler, "A "Post-Migrant" Theater Lexicon," Theatre Treffen Blog, May 2011, https://theatertreffen-blog.de/tt11/2011/05/11/sarrazin-migrationshintergrundneudeutsch-a-post-migrant-theatre-lexicon/

${ }^{20}$ Azadeh Sharifi, "Mapping Intellectual Networks: Postmigration, Theatre and Artists of Color" (Keynote Talk of Europe Now Festival, Amsterdam, 2013). https://azadehsharifi.wordpress.com/2013/05/17/europe-now-festival-in-amsterdammy-keynote-speak/. See also Azadeh Sharifi, "On the Representation of Artists of Color in German Theatre" (December 18, 2013). http://www.texturesplatform.com/?p=3237. Other helpful scholarship on a movement of postmigrant theater in Germany includes Jonas Tinius, "Authenticity and Otherness: Reflecting Statelessness in German Postmigrant Theater" Critical Stages, December 2016, Issue No. 14, http://www.critical-stages.org/14/authenticity-and-othernessreflecting-statelessness-in-german-postmigrant-theatre/; and Olivia Landry, "Greek Dispossession Staged, or When Street Politics Meets the Theater" TRANSIT vol. 10, no. 2. Instructive for a dance studies lens is Gabriele Brandstetter and Holger Hartung, eds. Moving (Across) Borders: Performing Translation, Intervention, Participation (Bielfeld: transcript Verlag, 2017).

${ }^{21}$ Sharifi, "Mapping Intercultural Networks".

${ }^{22}$ I borrow this link between dance improvisation and structuring change from my choreographer Susan Rose, who has referred to several improvisatory aspects of her work as "structures for change." While Rose does not consider herself or her dance works explicitly "political," she likes the fact that there may be something inherently political about this parallel between improvisation as a constant negotiation of change and the possibility of creating change through dancing on topics to do with power and communication. Phone interview with Susan Rose, May 9, 2016.

23 Jonas Tinius, "Rehearsing Detachment: Refugee Theater and Dialectical Fiction" Cadernos de Arte e Antropologica. Vol. 5. No. 1 (2016): 21-38.

${ }^{24}$ Kenneth Paul Kramer, Learning Through Dialogue: The Relevance of Martin Buber's Classroom. New York: R \& L Education, 2013, 83.

${ }^{25}$ Ibid.

26 Tinius, "Rehearsing Detachment," 29.

${ }^{27}$ For Kösterel, the process of working through common understandings of bodily experience, corporeal movements, and aesthetic reflection frees up space to move beyond the individual's singular story, and in doing so, expand the repertoire of what a person is beyond their political status, and beyond delimiting discussions of assimilation or integration. Stories of the past need not be ignored, but they can neither be fixed to the person performing him or herself for the benefit of the 
audience who, well-meaning as they may be, fall into an appropriative mode of spectatorship.

${ }^{28}$ Most often used in reference to second or third generation German artists, "postmigrant" offers an alternative to discussions of "Menschen mit

Migrationshintergrund," or German nationals with migrant backgrounds, which in turn, comes to name the theatre they make. For groups who identify with the postmigrant term, it has been important to redefine the image of the migrant in public discourse, such that the category of foreigner - even when generations removedloses the stigma of Outsider to attend to the myriad ways a "post-migrant society" might better recognize the demographic diversity of its citizenry.

${ }^{29}$ It is striking that in the same year that our project has taken shape, my father tried to acquire German citizenship for my siblings and me on account of our family's roots there. The application was rejected because it was my grandmother and not grandfather who had survived the Holocaust, a gendered distinction in official policy that several email rebuttals and harrowing accounts of my grandmother's family story could not overturn. While a compelling gap in official reparations discourse, I have no problems coming for brief visits to make art and see friends. I know that is my privilege speaking when I defend to the group that we can continue in hallways, language schools, and free spaces to continue making performance outside contracts that necessarily respond to state policy, aims, and concerns. It is my privilege, too, as a US academic to argue that performance networks that act outside of state sanctions move much more freely than those that require means of support and therefore subject themselves to the disciplining controls of administrative opinions, salable tactics, and marketable legibility. This disregard of any integration agenda is the product of the outsider status that I now comfortably occupy, and marks a kind of do-it-yourself pushback. It is also what has allowed us to meet and work without any formal record of our actions, something that has helped a project premised on working through issues raised by tenuous citizenship status.

${ }^{30}$ Beyond the realm of the interpersonal and intercultural dynamics shared in a creative collaboration, scholarship on post-migrant theater makes clear that an important aspect of its political work has been the degree to which theaters themselves support artists and artworks dealing with migration themes. While Dancing Exile has so far not affiliated with theatre venues or performing arts institutions, I recognize our project in Hamburg as part of a larger movement to diversify artistic representation in Germany from the point of view of those forced in or out of its bounds. 